\title{
La utopía socialista y el otro lado del "telón de acero" visto por viajeros costarricenses en el marco de la Guerra Fría
}

\author{
Recibido: $\quad 20$ de setiembre, 2019. \\ Aceptado: $\quad 27$ de abril, 2020. \\ Por: Dr. Carlos Manuel Villalobos ${ }^{1}$, Universidad de Costa Rica, \\ Costa Rica, Costa Rica.
}

\section{Resumen}

En este artículo se estudian los relatos de viaje publicados por cuatro escritores costarricenses que visitaron los territorios socialistas, también llamados los países de otro lado del "telón de acero" en el marco de la Guerra Fría. Estos textos muestran las simpatías ideológicas de los costarricenses con la Internacional Socialista, la Revolución China o la idea Juche del régimen coreano de Kim II-sung. Los escritores considerados son Joaquín Gutiérrez Mangel, quien visitó Polonia, la Unión Soviética y fungió como cronista de guerra en Vietnam; las memorias de viaje de Carlos Luis Fallas quien estuvo en la Unión Soviética y China; los relatos de Adolfo Herrera sobre su viaje a China y, finalmente, los escritos de Mario León Rojas dedicados a Corea del Norte. Estos viajes se realizaron entre 1949 y 1982, de modo que cubren casi todo el período de Guerra Fría. Más allá de la impronta anecdótica del viaje, estos escritos son un ejercicio de propaganda política. Mediante una estrategia hermenéutica, en este trabajo, se busca dar cuenta de los códigos discursivos. Se concluye que estos relatos se caracterizan por el tono encomiástico, la mostración de la épica revolucionaria y los logros del modelo socialista.

\section{Abstract}

\section{The socialist utopia and the other side of the Iron Curtain, as seen by Costa Rican travelers during the Cold War}

This article examines the travel accounts of four Costa Rican writers who visited socialist territories, known as the other side of the "iron curtain" countries in the context of the Cold War. These texts show the ideological sympathies of Costa Ricans with the Socialist International, the Chinese Revolution, and the Juche idea of Kim II-sung's Korean regime. The writers considered are Joaquín Gutiérrez Mangel, who visited Poland, the Soviet Union and Vietnam, where he served as war chronicler; the travel memories of Carlos Luis Fallas, who was in the Soviet Union and China; the travel accounts of Adolfo Herrera about his trip to China, and, finally, the writings of Mario León Rojas on North Korea. These trips were made between 1949 and 1982, covering almost the entire Cold War period. Beyond the anecdotal nature of these trips, the writings are an exercise in political propaganda. By resorting to a hermeneutical strategy, this work seeks to analyze the discursive codes. It concludes that these stories are characterized by the commendable tone, the display of the revolutionary epic, and the achievements of the socialist model.

1 El profesor Carlos Manuel Villalobos es Doctor en Letras y Artes en Centro América, graduado en la Universidad Nacional de Costa Rica. Labora como docente en la Escuela de Filología, Lingüística y Literatura de la Universidad de Costa Rica, Costa Rica. Contacto: carlos. villalobos@ucr.ac.cr.
Carlos Manuel Villalobos. La utopía socialista y el otro lado del "telón de acero" visto por viajeros costarricenses en el marco de la Guerra Fría. Revista Comunicación. Año 41, volumen 29, número 1, enero-junio, 2020. Instituto Tecnológico de Costa Rica. ISSN: 0379-3974 / e-ISSN1659-3820.

\section{PALABRAS CLAVE:}

Literatura de viajes, literatura costarricense, autores costarricenses, Guerra Fría, cortina de hierro.

\section{KEY WORDS:}

Travel literature, Costa Rican literature, Costa Rican authors, Cold War, Iron Curtain. 


\section{LOS SIMPATIZANTES DE LA UTOPÍA SOCIALISTA}

En 1931, se funda en Costa Rica el Bloque de Obreros y Campesinos que dará origen al Partido Comunista Costarricense. Entre los miembros de esta agrupación política destacan ideólogos que al mismo tiempo se dedican a la producción literaria y son quienes liderarán la ruptura estética que Álvaro Quesada (1998) define como el paso de la unidad a la escisión en la historiografía literaria costarricense. Según Quesada, entre 1920 y 1940, las propuestas de esta generación se destacan por "una premonición del caos" como antesala del fenómeno de la heterogeneidad literaria. Esta perspectiva estética tendrá en la revista Repertorio Americano ${ }^{2}$ un espacio que enlaza con el resto del mundo hispano. Por esta razón, Quesada, entre otros estudiosos de la literatura costarricense, Ilamará a esta agrupación emergente como la generación del Repertorio Americano o Vanguardia.

A partir de 1943, el Partido Comunista se denomina Vanguardia Popular y entre sus miembros activos se mantienen importantes escritores nacionales. La Ilamada generación del 40 (Quesada-Soto, 1998) reafirma los postulados ideológicos que derivan de la preocupación por la proletarización y marcan el nacimiento de una narrativa realista. Rojas y Ovares en el texto 100 años de la literatura costarricense (1995) Ilamarán a este fenómeno "De la montaña a la costa", pues los temas literarios trascienden el ámbito capitalino y producen un "reacomodo de fuerzas políticas y económicas que condujo al rompimiento temporal del régimen democrático" (1995, p 97).

En este contexto, vinculados con el ideario socialista, surgen nombres de escritores como Joaquín García Monge (1881-1958), Carmen Lyra (1887-1949), Omar Dengo (1888-1928), Carlos Luis Fallas (19091966), Adolfo Herrera García (1914-1975), Fabián Dobles (1918-1997) y Joaquín Gutiérrez Mangel (1918-2000), entre otros. Estas voces le heredarán a la historiografía literaria una propuesta enunciativa

2 La revista Repertorio Americano, dirigida por Joaquín García Monge, circuló de 1919 hasta 1958. Jugó un papel clave en la tarea de articular el pensamiento crítico de una generación que coincidió en preocupaciones sociales y participó de la utopía ideológica socialista. Fue también la plataforma de una perspectiva global que a la postre motivaría algunos de los viajes que emprendieron los autores en este contexto. que pone en juicio los procedimientos de la hegemonía capitalista y que promueve un reacomodo de las instancias sociales.

Como estrategia para alcanzar el estado de equidad que se proponen, estos intelectuales comulgan con las experiencias socialistas de la Unión Soviética y de los demás países vinculados con la Internacional Comunista. Son promotores ideológicos de un cambio global que tiene como misión romper con el modelo de la acumulación desigual. En el contexto de la posguerra mundial a mediados del siglo XX, se intensifica la oposición entre ambas ideologías y el mundo entra en una dinámica que se conoce como la Guerra Fría. El bloque de la Organización del Tratado del Atlántico Norte (1949) se enfrenta a los países del Pacto de Varsovia (1955). Este nuevo escenario geopolítico instala su frontera más importante en Europa. Gracias a una ocurrencia que se le atribuye a Winston Churchill, el bloque capitalista recurre a la metáfora de la "cortina de hierro", para caracterizar la separación que existe entre ambos bloques. En este contexto, los escritores costarricenses aliados a la perspectiva ideológica del Pacto de Varsovia y los demás aliados, quedarán, geográficamente, del lado opuesto.

En esta investigación se analizan los relatos de viaje de los autores costarricenses que cruzaron este "telón de acero" en función de su simpatía ideológica con la Internacional Socialista, la Revolución China o la idea Juche del régimen coreano de Kim Il-sung. Se consideran las crónicas de Joaquín Gutiérrez Mangel, quien visitó Polonia, la Unión Soviética y fungió como cronista de guerra en Vietnam; las memorias de viaje de Carlos Luis Fallas, quien estuvo en la Unión Soviética y China; los relatos de Adolfo Herrera sobre su viaje a China y los escritos de Mario León Rojas dedicados a Corea del Norte.

\section{JOAQUÍN GUTIÉRREZ: EL PARTIDARIO DE LA PAZ}

En 1939, Joaquín Gutiérrez Mangel, campeón de ajedrez de Costa Rica, viaja a Argentina para participar en la olimpiada mundial de esta disciplina. Decide que no regresará a su patria natal y desde este 
país sudamericano planea dirigirse a Francia, pero la Segunda Guerra Mundial se le atraviesa en el camino y el joven ajedrecista se ve obligado a cambiar de planes. Opta por dirigirse a Chile, pues ahí, según el escritor, "había nieves eternas (...) las chilenas eran muy guapas y, tercero, el Frente Popular acababa de elegir Presidente de la República a don Pedro Aguirre Cerda" (Gutiérrez, 1989, p.170). Oficialmente, reside en esta nación por más de treinta años, los cuales incluían sus estadías en China y la Unión Soviética. En 1973, se ve forzado a regresar a Costa Rica pues resulta non grato para el régimen golpista que derroca a Salvador Allende.

Durante la estadía en Chile, Gutiérrez reafirma los ideales socialistas que en Costa Rica lo habían ligado al Partido Comunista. El contexto político chileno antes del golpe, identificado con las ideas socialistas, le facilitan varios viajes a los países del otro lado de la llamada "cortina de hierro".

La primera gira que documenta ocurre a finales de 1949 e inicios de 1950, cuando estuvo en Polonia como delegado al Congreso Mundial de la Paz. Las crónicas de este viaje fueron publicadas como libro por la Editorial Austral en 1952, bajo el título Del Mapocho al Vístula: crónica de viaje. De 1960 a 1962, trabaja en Beijing en la Editorial de Lenguas Extranjeras (1989, Tomo III, p, 257). Posteriormente, se traslada a Moscú donde labora como corresponsal para el periódico chileno El Siglo. De esta experiencia en la Unión Soviética surge el libro La URSS tal cual que será publicado en 1967. Otro de los viajes memorables como corresponsal ocurrirá en 1966, pues consigue que el Viet Cong le autorice un ingreso para informar sobre la guerra de Vietnam. Se le permite hacer un recorrido por el país y el propio presidente $\mathrm{H} \square$ Chí Minh acepta conversar con el escritor. Estas crónicas, publicadas originalmente en el periódico, son retomadas y editadas en 1988 bajo el título Vietmam, Crónicas de Guerra. Otros textos adicionales, referidos a la estadía en la Unión Soviética serán recopilados en 1999 y publicados como Crónicas de otro mundo. Este mismo año, justo antes de su muerte, se publicará también el libro de memorias titulado Los azules días.
El formato discursivo de estos textos se ajusta a la extensión de un artículo corto para ser publicado en un periódico. Cada texto es antecedido por un título que lo identifica. Este estilo se mantiene desde la primera publicación en 1952 referida a su participación en el Congreso Mundial de la Paz en Varsovia. Antes de la edición que hiciera la Editora Austral, estas primeras crónicas se habían publicado en el diario chileno Democracia. En la versión príncipe, la primera crónica se titula "Nos fuimos". Para las Obras completas de 1989 el autor rescribe el texto, elimina algunos apartados e inserta otros. Algunos de los capítulos que escribe para esta última versión responden a asuntos que, en su momento, no quiso publicar como, por ejemplo, la revelación de dos confesiones que hiciera Gabriela Mistral a él y a Pablo Neruda durante una reunión con ella en Italia. Una está referida a la muerte de un sobrino de la autora, y la otra al suicidio del novelista austriaco Stefan Sweig y su esposa, luego de que esta le confesara que era agente nazi. También, hay cambios en el orden de algunos de los apartados. Por ejemplo, en la nueva versión "Nos fuimos", aparece de tercero y antes incluye dos textos que funcionan como preámbulo anecdótico. En esta nueva edición comenta que:

comencé a relatar a grupos de amigos lo que había visto durante los 200 días en que anduve recorriendo Europa; esos grupos crecieron y durante algunas semanas casi no hice otra cosa que ir de casa en casa relatando anécdotas y peripecias. Aquellas charlas se convirtieron luego en crónicas periodísticas y así, durante un par de meses, me di el gusto de "conversar" ya no con decenas de oyentes sino con miles de lectores. (1989, Tomo III, p. 169)

La versión original se caracteriza por la inmediatez y es mucho más amplia. La nueva versión replantea la enunciación siguiendo el formato de la memoria de viaje y en algunos de los apartados resulta una especie de resumen de la anterior. Por esta razón, en la edición de 1989 se excluyen algunos puntos que se refieren a la cercanía del hecho. Originalmente, el texto ubica al lector en la víspera del viaje y reflexiona sobre la experiencia que está a punto de vivir. Un ejemplo de esto es la siguiente acotación: 
“Dices que partir es morir un poco y ante esa muerte pequeña son necesarias algunas reflexiones simples. Algo como decir: -me voy, y ¿qué queda detrás de mí?, ¿qué dejo?, ¿qué he hecho?" (1952, p. 6). En la versión de 1989, elimina estas acotaciones y corrige algunas imprecisiones, como la aseveración equivocada de que el Congreso para la paz sería en Sheffield, Inglaterra. En otras palabras, las modificaciones responden a un replanteamiento de la estrategia enunciativa, propuesta ahora como memoria, pues se elimina la inmediatez y se recurre al distanciamiento temporal ${ }^{3}$.

Si bien Joaquín Gutiérrez va al Congreso en representación de Costa Rica, gracias a la designación hecha por el escritor Joaquín García Monge, se declara chileno en las inquietudes que lo acompañan. Confiesa que "voy acongojado porque dejo a Chile con heridas abiertas de cuyos gruesos labios mana sangre" $^{\prime \prime}(1952$, p. 6). Al mismo tiempo, declara que sale de Chile y es a los chilenos a quien quiere rendirles cuentas (1952, p.7).

A modo de resumen prospectivo, escribe que durante el viaje conoció desde "el ensangrentado y medieval régimen franquista hasta el novísimo de las democracias populares. Pasé cuatro veces la cortina de hierro, dos para un lado y dos para el otro, levantándola todas las veces con un dedo" $(1952$, p. 7). Esta última imagen es una ironía donde revela el rechazo que siente por esta metáfora cliché. Más adelante, cuando se refiera al vuelo de ida rumbo a Varsovia, al entrar a territorio alemán, cuenta que uno de los pasajeros bromeó con la idea de que iban a chocar con la cortina de hierro. Acto seguido, señala que el chiste fue celebrado por un cura católico, un laborista británico, un poeta chileno, un profesor australiano, un abate francés y un ferroviario peronista, entre otros pasajeros. Mediante esta pluralidad de risas, el escritor desacredita la metáfora y la presenta como una construcción ideológica inventada por los detractores para expresar la posición férrea del modelo socialista. Agrega que "todos en el avión sabíamos que la cortina que Churchill inventó y bautizó es sólo un mero pretexto para armarse, para agredir a Corea,

3 Para efectos de esta investigación se seguirá citando la versión original de 1952, pues es mucho más amplia y coincide con la publicación que circuló previamente en el diario Democracia. para ametrallar a los obreros tunecinos, para explotar a los mineros bolivianos, para comprar barato y vendernos caro" (1952, p. 25).

Gutiérrez, por la identificación ideológica, ve en el otro lado de la "cortina" un espacio de diferencia, donde se cumplen los valores humanos de la igualdad, la paz y la justicia. De ahí que, para él, como lo será en su momento también para Carlos Luis Fallas, el viaje a este otro mundo significa el cumplimiento de una añoranza. Si se guardan las diferencias, se podría comparar con el viaje del motivo religioso, donde los peregrinos son impulsados por la idea de conocer un sitio que tiene un valor sagrado. En este caso, la sacralización la representa el sistema idealizado. Si los peregrinos que cuentan sus experiencias de viaje asumen una misión evangélica; los viajeros que cumplen su deseo de conocer el sistema comunista proclaman las virtudes de la utopía.

Estos viajes, por su parte, contribuyen a demostrar la coherencia de los escritores, pues hay un sentimiento de lealtad de partido si las giras se hacen a estos contextos. Un viaje a los países capitalistas podría, en este contexto, resultar sospechoso. Esta bipolaridad, además, garantiza la identificación de los aliados más allá de las fronteras nacionales, pues los camaradas se lanzan guiños de simpatía a sabiendas de que comparten el mismo imaginario político de la Internacional Socialista.

En relación con las vicisitudes del viaje, Gutiérrez cuenta que navega en tercera clase en un barco argentino llamado Salta. Las condiciones no son las más aptas, pero el joven escritor aprovecha para interactuar con sus compañeros y relatar las anécdotas que le ocurren de camino y aquellas que le van contando. Desde la embarcación, describe los escenarios geográficos de Argentina y Brasil mediante un paneo visual, pero no puede tocar tierra pues los de su clase no tienen permiso para descender. Una vez en España, permanece cinco días en Madrid y luego se dirige a París en tren. La España franquista le parece deplorable. Ofrece datos sobre el deterioro social y se lamenta de la situación de la siguiente manera: 
“Pobre España cómo nos pesa en el corazón4. Hace doce años diste la sangre de dos millones de muchachos muertos en los campos de batalla y en las prisiones" (1952, p. 14).

La llegada a París le genera una emoción especial no solo por el prestigio cultural de la ciudad y ser el lugar del Cholo Vallejo, sino porque de esa ciudad es la familia Mangel, su apellido materno. "Es el París de la infancia de mi madre; tengo su foto, ella adolescente en el Bosque de Boulogne acompañada de mis tías. Allí tenía mi madre 15 años de edad, no se imaginaba que iba a casarse y tener sus hijos en la América tropical" (1952, p. 16). Sin embargo, Francia no tiene el significado ideológico que tendrá Varsovia, su destino principal, pues como bien apunta en sus crónicas este sitio será la primera ciudad del mundo socialista que le tocará conocer.

Antes, sin embargo, el avión aterriza en Praga y el escritor experimenta un adelanto de lo que podríamos definir como la semiosis de la utopía socialista, pues en suelo checoslovaco los jóvenes salen a recibir a los recién llegados con flores, cantos y gritos de vivas a la paz. Como símbolo fundamental del ideario comunista al fondo se observa la emblemática bandera roja. En la versión de 1952, el apartado VIII se titula "Un aeropuerto en Praga", pero en la edición de las Obras completas se cambia a "Las banderas rojas". Se advierte aquí el énfasis en el motivo ideológico. En ambas versiones el autor vincula este color con sus memorias infantiles a propósito del ideario sandinista de Nicaragua con el que se identifica desde entonces. Curiosamente, en la versión de 1989, Gutiérrez excluye el pasaje donde recuerda que su amigo, el poeta Pablo Neruda, al asomarse por la portezuela del avión, es ovacionado por los checoslovacos.

Al llegar a Varsovia el escritor se ve sorprendido por las señales de destrucción que aún permanecen en la ciudad luego de la guerra. Describe el panorama de la siguiente manera:

Varsovia fue la primera ciudad destruida por la guerra que conocí. Son seis cuadras, ocho cuadras, doce cuadras al correr del autobús y sólo

$4 \quad$ Evidentemente, esta acotación es un intertexto del título del poema España en el corazón (1937) de Pablo Neruda. miro esqueletos de casas calcinadas, como inmensas dentaduras podridas: hierros retorcidos, montones inconcebibles de ladrillos, huesos humanos, boquetes gigantescos de los obuses, a través de los cuales se ve un pedazo plomizo del cielo otoñal. De pronto un cuadro familiar que resulta grotesco y de vértigo: en un cuarto piso una familia reunida cenando, en una pieza sin pared a la calle, abierta al vacío; allí comen, conversan, se adivina que ríen (1952, p. 20).

La retórica literaria de esta descripción sirve de preámbulo para plantear una apelación a la conciencia de sus destinatarios chilenos. Ofrece el dato de que de cada seis personas en esta ciudad murieron tres, luego propone el ejercicio de imaginar a cuáles miembros de sus familias escogerían si se diera un caso similar. Intenta, de este modo, apelar a la conciencia de los chilenos a partir de los vínculos filiales.

Entre las funciones discursivas medulares de esta crónica se destacan, en primer lugar, la referencial, a propósito de la enunciación descriptiva y la narración de los acontecimientos vinculados propiamente con el Congreso; en segundo lugar, aparece una función emotiva vinculada con los enunciados autorreferenciales, a propósito de lo anecdótico y las impresiones personales. Finalmente, hay una función apelativa que se refiere a la defensa de la utopía socialista frente a los cuestionamientos que le hace al modelo capitalista que lidera Estados Unidos.

Menos relevante será la función poética a la que también recurre eventualmente, sobre todo en el contexto de los enunciados laudatorios que le hará al modelo comunista. Un ejemplo de esa función retórica es el siguiente enunciado donde se idealiza el sistema que gobierna a Polonia: "Y allí, a horcajadas sobre el Vístula que la baña y la fecunda, comenzó a brotar de nuevo la más radiante primavera humana" (1952, p. 22).

Como ya hemos dicho, el enunciado encomiástico funciona como estrategia retórica para promocionar las virtudes del modelo socialista. En coincidencia con el espíritu de la ideología marxista-leninista cree, como muchos en este contexto, que el mundo se 
enrumbará hacia un cambio socialista. Los primeros países en montarse en este carril soviético son Polonia, China, Checoslovaquia, Hungría, Bulgaria, Rumanía y Albania. Gutiérrez cree que nadie los fuerza a recorrer este camino, excepto su propia voluntad popular. Se pregunta hacia dónde se dirigen y se responde de este modo: "Hacia una sociedad en la cual no existirá más la explotación del hombre por el hombre, un mundo en el cual la naturaleza será la esclava dócil de la humanidad" (1952, p 69). A esta enunciación utópica le añade la presentación de datos estadísticos que intentan demostrar que los resultados son positivos.

Aunque las crónicas hacen referencia a lo sucedido durante el Congreso, este tema resulta secundario. En todo caso, las alusiones a la actividad se esbozan desde una mirada contemplativa, pues el escritor se siente cohibido ante la presencia de connotadas figuras tales como Jorge Amado (escritor brasileño), Kuo Mo Jo (vicepresidente de China) o la escritora alemana Ana Seghers, entre otros. No obstante, Gutiérrez es designado por los congresistas para ocupar uno de los asientos del presídium. Al respecto, el escritor confiesa que se sintió sorprendido, pues no se sentía digno de tal honor. Le atribuye "el mérito a la pequeña Costa Rica, mi patria, y a mi gran pueblo chiquito, que lucha valeroso por forjar un destino mejor" (1952, p. 27).

La mayoría de las referencias y anécdotas de las crónicas se centrarán en las personas y los escenarios, especialmente los de Polonia, pues este será el país donde estará la mayor parte del tiempo. Aquí, por ejemplo, es sorprendido por un niño polaco quien le obsequia una moneda de recuerdo y se niega a recibir algo a cambio. Gutiérrez lo toma en brazos y al darle un beso de agradecimiento recuerda a sus hijas en la distancia y los niños de América. Confiesa que esta escena hizo que se le llenaran los ojos de lágrimas. Este niño funciona como ejemplo de los valores nuevos y representa, al mismo tiempo, la contraparte del modelo capitalista. De hecho, el apartado que se titula: "Los niños de Varsovia", cierra con una crítica a la desinformación de la prensa estadounidense, pues en una noticia se dice que los niños polacos, muertos de hambre, piden limosna a los extranjeros.
El autor se lamenta de que probablemente esa mentira resulte más creíble que su testimonio.

Como lo hará luego en sus distintas crónicas, Joaquín Gutiérrez transcribe conversaciones con los actores populares. En este caso, habla con campesinos y otros trabajadores. Uno de los apartados transcribe una conversación con una mujer que pone ladrillos en una construcción y descubre que es una persona culta a la que le gusta la literatura. Lo mismo hace con los guías que le traducen durante sus recorridos. Uno de los casos es el de un joven de unos 35 años, quien le muestra a él y a sus acompañantes el campo de concentración Auschwitz. Durante este recorrido el costarricense forma parte de un grupo en el que están la profesora y activista chilena Olga Poblete junto con los poetas españoles Rafael Alberti y José Bergamín. Indica que "Después de dos horas de recorrer ese páramo de muerte, deseosos de escapar de esa pesadilla ya intolerable y escuchar algo que nos dijera del triunfo de la vida, se convirtió en una necesidad imperiosa preguntarle su historia" (1952, p. 50). El guía habla de su experiencia como prisionero y les muestra su número tatuado en el brazo.

Entre otros de los muchos lugares que visita en Polonia están la casa donde vivió Chopin; la residencia de María Walewska, quien fue amante de Napoleón y el Castillo de Wawel. Recorre también sitios rurales y, aparte de Varsovia, permanece varios días en Cracovia. Asistirá también a funciones teatrales, cinematográficas y circenses. Polonia es vista como un lugar promisorio. No escatima elogios para referirse a la reconstrucción y desarrollo humano del país. Incluso, al compararla con la vecina Alemania Occidental considera que existe gran diferencia, pues en el país de al lado, se han dedicado a construir fábricas, pero las ciudades siguen en ruinas. En su opinión:

Han pasado los mismos años que en Varsovia, pero los años no se pueden medir solamente por los relojes y los calendarios; hay que medirlos también por el corazón de los hombres; y en Polonia se han creado las condiciones necesarias para que el corazón de los hombres haga milagros (1952, p. 23). 
Otro de los temas a los que hace referencia es la conocida religiosidad de los polacos y su identificación con el mito mariano. En 1947, la Virgen de la Catedral de Lublin fue noticia nacional pues se decía que Iloraba sangre. Este hecho provocó que miles de campesinos abandonaran sus trabajos agrestes para venir a presencial el milagro. Al año siguiente, el mismo fenómeno ocurrió en una ciudad del norte y de nuevo miles de peregrinos corrieron al lugar. El gobierno notó que los milagros ocurrían en la época de recolección de cosechas y, "para que a nadie se le fuera ocurrir que aquello podía formar parte de un plan deliberado de sabotaje a la producción, prohibió los milagritos" (1952, p. 41). Es evidente que el tono irónico con el que se cuenta esta anécdota denota un cuestionamiento tácito de la creencia católica.

Como ya hemos apuntado, la convocatoria al Congreso Mundial de la Paz hizo que asistieran importantes escritores con los que Gutiérrez hace o tiene, de previo, amistad. A Pablo Neruda lo acompañará en varias ocasiones ${ }^{5}$. En Polonia, lo hará a los montes Tatra, en la estribación de los Cárpatos, para hablar con el escritor polaco Jerzy Borejsza, quien tiene la tarea de traducir el Canto General. En Checoslovaquia, lo acompañará a una firma de libros que se torna interminable y que agota la edición checa del libro Que despierte el leñador. En Italia, se volverá a encontrar con el poeta chileno y esta vez lo acompañará a Murano, una isla donde abundan los sopladores de vidrio. También irá con él a Rapallo a un encuentro con Gabriela Mistral. Sobre esta reunión a solas con los que serían los dos premios Nobel de Chile, el costarricense escribe:

Al verlos a los dos juntos yo no podía dejar de pensar en el destino de Chile a quien le cupo la gloria de dar dos de sus hijos, del norte chico y del sur lluvioso, ambos morenos con la ju-

$5 \quad$ En la versión para las Obras Completas, Gutiérrez dirá la mayor enseñanza de este primer viaje por Europa la logró en compañía de Pablo Neruda. Al respecto comenta que "no es lo mismo Neruda rodeado de enjambres multicolores que lo visitan y asedian en Chile, que Neruda solo, con su maravillosa Hormiguita, y dos o tres amigos más, recorriendo con él las calles Venecia o Cracovia, rebuscando viejos libros a las orillas del Sena, tratando de comprar "un caballito" en Verona, o simplemente gozando de la oportunidad de preguntarle lo que se me viniera a la cabeza" (1989, p. 250). gosa sangre indígena, para que se convirtieran en dos de los más grandes poetas de nuestra lengua (1952, p. 91).

Una vez que abandona Polonia, Gutiérrez se dedica a recorrer Europa. El siguiente país será Checoslovaquia. Aquí, sin embargo, a pesar de que está diez días, no puede disfrutar plenamente, pues permanece tres días enfermo. De Praga vuela a París, en donde se queda tres meses. Ahí experimenta el placer de recorrer a pie la ciudad y de asistir a diversas actividades culturales donde se encuentra con destacadas figuras de la cultura. Aprovecha, también, para mejorar sus conocimientos sobre la lengua francesa. Su siguiente destino es Italia. En Turín se rencuentra con un hermano suyo. Luego va a Venecia, Milán, Génova y Roma.

Durante la estadía en Venecia, Gutiérrez acompaña a Neruda a un encuentro con dirigentes sindicales del gremio de los obreros. Los italianos le piden unas palabras y lo llaman el partiggiano della pace. En este escenario, el escritor se refiere a Costa Rica y describe de la siguiente manera los acontecimientos bélicos de la guerra civil de 1948:

Yo les conté de mi país. De cómo mi pueblo había consolidado la democracia, adquirido la libertad y ganado algunas leyes sociales, hasta que llegó un momento en que los terratenientes aliados con las empresas imperialistas se lanzaron a la guerra civil. El pueblo de Costa Rica no pudo conseguir armas y en cambio las fuerzas de la reacción contaron con todas las que quisieron. Y así, heroicamente, librando una lucha desconocida y mal interpretada por todos, inclusive por los pueblos hermanos de América Latina, sin ninguna esperanza de poder ganar, fueron segadas 3.000 vidas de obreros y campesinos hasta la derrota total (1954, p. 88).

Es obvio que la visión de la guerra que le narra Gutiérrez a los italianos parte del punto de vista de los comunistas que, en ese contexto, se aliaron al oficialismo. Sin embargo, a pesar de que llama a Figueres falangista, los cuestionamientos al gobierno de Costa Rica no son tan fuertes como los que emite en este 
mismo texto a propósito de la dictadura somocista en Nicaragua.

En estas crónicas, tal y como lo anunció al inicio, el escritor escribe para un enunciatario chileno. Sin embargo, en sus preocupaciones alude con frecuencia a la situación de su país natal y del entorno centroamericano. Después de todo, va en representación de Costa Rica con el visto bueno de sus compatriotas socialistas.

Gutiérrez regresa a París y ahí se encuentra con su Esposa. Con ella recorrerá de nuevo Polonia, Checoslovaquia e Italia. Irán también a Austria y Portugal. Al regreso, de nuevo a las orillas del río Mapocho en Chile, el escritor confiesa que el viaje le ha deparado mayor esperanza y fe en el destino de la humanidad. Considera que ahora tiene "total seguridad de que a nuestras hijas les dejaremos un mundo mejor" (1952, p. 93). Se refiere, desde luego, a sus propias hijas; pero se infiere que habla también en nombre de una herencia colectiva que aspira a la utopía de la justicia social.

\section{BAJO LAS BOMBAS DE VIETNAM}

El ideario que defiende Gutiérrez en este primer viaje a Europa, lo reafirma con más contundencia en las crónicas que darán cuenta de un viaje a Vietnam en 1966, en pleno conflicto bélico. Una selección de estos textos dará origen a un libro titulado Vietnam Crónicas de Guerra que publicará en Costa Rica en 1988. En la introducción, que titula "Unas pocas palabras" acota lo siguiente:

Hoy, 22 años después, esas crónicas volanderas tomarán forma de libro. Lo hago porque creo que conservan su actualidad. Hoy de nuevo muchos pueblos, aquí mismo en Centroamérica, así como en muchas otras partes del mundo, están entregando ríos de sangre, como Vietnam lo hizo, en su determinación de obtener su plena libertad y soberanía. (1989, p. 259)

La crónica de guerra no tiene una tradición reconocida en Costa Rica. Los primeros textos, que se registran, en el siglo XIX, corresponden a los informes oficiales que se enviaban desde Nicaragua en el marco de los acontecimientos bélicos de 1856. Otro texto que alude a un conflicto armado ocurrirá en el contexto de la Guerra civil española. Aquí, específicamente nos referimos al libro España Heroica que publicó Vicente Sáenz en 1938 a modo de recopilación de varios artículos previamente divulgados en la prensa. Sin embargo, este texto de Gutiérrez es el único en su género que se enuncia como un reportaje de guerra, con las consecuencias riesgosas que esto implica.

En 1965, Estados Unidos arremete contra Vietman. Las consecuencias civiles de los ataques militares generan un repudio internacional en aquellos sectores que se oponen a las políticas norteamericanas. La prensa ofrece informaciones que muestran algunos de los daños. Desde luego, Joaquín Gutiérrez, quien en ese momento reside en Moscú, forma parte de los que condenan los ataques y decide solicitar una visa para ingresar como corresponsal de guerra. Hasta ese momento, según narra el propio escritor, con autorización vietnamita, solo habían ingresado Wilfred Burchett, corresponsal australiano y a Madelaine Riffaud, periodista francesa del diario "L'Humanité" (1989, p. 258). La embajada de Vietman en Moscú estudia la solicitud y cinco meses después le informan que ha sido autorizado su ingreso. De inmediato vuela de Moscú a Ulan Bator, la capital de Mongolia, y luego vía Beijing conecta con Hanói. Antes de salir de territorio chino, el avión hace una parada estratégica en Nanning, una ciudad ubicada cerca de la frontera vietnamita, pues unos aviones de caza estadounidenses sobrevuelan la zona. En el aeropuerto chino, Gutiérrez descubre que el mínimo calor activa los sensores de los cohetes de la defensa y debe apagar el cigarro como medida de seguridad. Una vez que ha pasado el peligro, el avión continúa hacia Hanói. Al cruzar la frontera del país en guerra, Gutiérrez describe la sensación de la siguiente manera:

Me latían las sienes, tenía la garganta llena de palabras y nadie con quien compartirlas. Y sobrepuestas al paisaje, según viendo las "narices rojas" atisbándome golosas. Todo eso junto hizo que de pronto me sintiera solo, muy solo, colgando de las nubes, metido en una gran 
"aventura" y sin saber cómo iría ésta a terminar. (1989, p. 263)

En el aeropuerto de Hanói le preguntan si la cámara que trae tiene rollos para fotografías a color. No estaban permitidas las tomas a color pues distinguen la diferencia de tono entre el verde natural y el camuflaje. El reportero informa que solo trae para blanco y negro y recibe el visto bueno de las autoridades de migración.

Durante la estadía escribe por lo menos una crónica al día que es trasmitida a la Agencia de Prensa Vietnamita y retrasmitida, primero a TASS (La Agencia de Telégrafos de la Unión Soviética) y luego a Prensa Latina. Gracias a la ventaja del horario, la mayoría de los reportajes se publicaban en Chile al día siguiente de haber sido escritos (1989, p. 259).

Uno de los primeros datos a los que se referirá es el número de aviones que ha derribado la resistencia. El día de llegada, Au, el guía que lo acompañará, le cuenta que acaban de ser derribados dos aviones invasores. Al día siguiente, Au llega a buscarlo al hotel y trae la noticia de que acaba de ser derribado el avión número mil. Como resultado de la emoción, escribe:

Comenzamos a dar vivas, a toda voz, yo en español y él en vietnamita. Jamás me habría soñado que mi viaje comenzaría con una noticia así. Y cuando Au, ya más sereno, me pide excusas por haberme despertado en esa forma, le digo que ojalá tenga un notición de ésos cada día, aunque yo termine muerto de sueño. (1989, p. 267)

Durante los primeros días, Gutiérrez permanece en la capital a la espera de la autorización para hacer un recorrido por el país. Junto con su guía visita distintos puntos de la ciudad, tales como: el zoológico y los parques públicos. El Primero de mayo va a una función teatral a la que asiste el propio Hô Chi Minh. Esta fue la primera vez que vio al líder y le produjo una emoción especial que repetiría días después, cuando consiguió que el "tío Hô" le concediera una entrevista.
El 2 de mayo, por la tarde, con un chofer, el guía y dos funcionarios del gobierno, salen de Hanói rumbo a Saigón. Por seguridad, deben viajar de noche. Algunos de los puentes han sido destruidos, pero existen sistemas de reparación provisional que desmontan durante el día. Asimismo, para evitar aglomeraciones frente a los puentes, en algunos ríos, hay bifurcaciones con varias opciones para pasar. Además, existe un sistema de avisos que funciona como un semáforo. Gutiérrez lo explica de la siguiente manera:

Cada cierto trecho un soldado, medido en una trinchera -más exactamente en un simple hueco cavado en la tierra- escucha por radio las informaciones del radar, anunciando cuando venía una escuadrilla enemiga. Entonces el soldado asomaba una lámpara, hecha con un cabo de bambú, con tres "ventanitas" cubiertas con celofán de colores diferentes. El amarillo indica que no había peligro y continuábamos la marcha a unos 30 ó [sic] $40 \mathrm{Km}$ por hora y con los focos encendidos (los focos, eso sí, cubiertos con viseras de bambú — todo parecía hecho de bambú- para que su luz no se "elevara"). El color azul indicaba peligro; el chofer apagaba todos los focos —aquí era cuando adquirían enorme importancia los ojos de gato- y continuábamos la marcha, por entre la muchedumbre, a unos $20 \mathrm{~km}$ por hora. El rojo indicaba que los aviones estaban ya encima. Entonces todo se detenía, el "jeep" frenaba en seco, saltábamos a tierra y había que meterse en unos zanjones o trincheras abiertos a todo lo largo de la carretera (1989, p. 279).

Durante uno de los recorridos, el reportero costarricense es testigo de un ataque aéreo que lo obliga a salirse del carro y tirarse al suelo. Por encima pasa una escuadrilla de bombarderos estadounidenses que deja caer varias bombas. El periodista describe el sonido de los retumbos y la iluminación que provocan los estallidos. Acota que siente el corazón "zapateándome como loco, pero me esfuerzo por mantener todos los sentidos alerta" (1989, p. 285).

Para Gutiérrez, el heroísmo de los vietnamitas, la experticia histórica y los resultados de la resistencia 
permiten prever que Estados Unidos será derrotado. Vaticina que la moral de los invasores jugará en contra de ellos y que al final, no importa el tiempo, los asiáticos vencerán. Un ejemplo de la audacia luchadora es la defensa del puente Ham Rong que hasta ese momento había sorteado unas 2000 bombas enemigas. Esta construcción de 500 metros de largo es estratégica, pues permite el tránsito terrestre del norte hacia el sur y viceversa. La anulación de este paso era estratégica, pero los bombarderos no lo lograron debido a las condiciones geográficas y a la artillería terrestre que les impedía acercarse.

Otra de las argucias militares es la red de túneles que existen desde la invasión francesa. Este mecanismo de evasión subterránea tiene dos niveles por si el enemigo consigue entrar o utiliza armas lanzallamas. Frente a esta audacia, Gutiérrez expresa: "—Ah, hijos de ángeles con diablillos! [sic] Que combatían así, con sus instrumentos de labranza o con armas que le capturaban al enemigo" $(1989,321)$.

En las crónicas el visitante da cuenta de las conversaciones con las personas que participan en la resistencia. No solo transcribe las preguntas y las respuestas, sino que también expresa las emociones que lo embargan en el contexto de la entrevista y la entereza que advierte en la gente del pueblo. En ocasiones expresa la emotividad mediante un apretón de manos o un abrazo. Uno de los entrevistados que lo conmueve es el desarmador de bombas, que no tuvo preparación previa y lleva ya siete desarmadas con éxito. Gutiérrez describe del siguiente modo su reacción: "Me pongo de pie, le doy un abrazo — tiene los huesitos frágiles - y lo felicito por su heroísmo" (1989, p. 302).

Otras veces bromea con los entrevistados. A una de las jóvenes fusileras que logró derribar un avión le pregunta, de repente, por su novio. "Y ante esa pregunta la muchachita, que no parpadeó frente al avión enemigo, se disuelve como un terrón de azúcar en el agua y todos los rubores de la adolescente campesina se le suben al rostro" (1989, p. 304).

Además de elogiar el desempeño bélico, Gutiérrez aplaude los logros socioeconómicos del modelo socialista. Para comprobar el éxito del modelo político recurre a los datos estadísticos oficiales. Señala que la producción de arroz es ahora mucho mayor que en años anteriores, pues las técnicas de cultivo han mejorado la cantidad de quintales por hectárea. Las mejoras también aplican para el sector industrial. Originalmente los franceses habían recurrido a la industria textil para explotar a los pobladores, pero ahora en manos del pueblo hay más producción. Agrega que, además, cuentan con leyes sociales y que el nivel de la enseñanza ahora es superior.

Al regreso a Hanói, después del largo recorrido, consigue la añorada entrevista con los más altos funcionarios del gobierno vietnamita. Lo recibe el Primer Ministro Pham Van Dong y, mientras transcurre la conversación, aparece el propio Hô Chi Minh. El escritor relata que el presidente: “...me tomó ambas manos, me condujo al sofá y se sentó a mi lado pero si somos camaradas- me dice" (1989, p. 229). El visitante confiesa la emoción que experimenta al encontrarse al frente del líder vietnamita. Le cuenta que él lo leía desde 1936, en una revista de la Internacional que llegaba clandestinamente a Costa Rica. Durante la conversación hablan de literatura y luego sobre los temas políticos y el conflicto armado.

Es evidente que Gutiérrez no hace este viaje por razones meramente periodísticas. Se advierte una clara identificación con la causa ideológica. Mezcla lo anecdótico y el dato periodístico con diversas acotaciones encomiásticas. Cree en el principio de la dialéctica histórica que camina hacia el modelo socialista. Concluye que:

En Vietnam en guerra se aprende, mejor que en ninguna otra parte, que la historia no late al mismo ritmo que el corazón humano; que la lucha contra el imperialismo va a durar decenios - los vietnamitas, desde que los colonizaron los franceses, duraron más de un siglo luchando por liberarse-; que durante esos próximos decenios los pueblos van a obtener muchas victorias (1989, p. 244).

A diferencia de Vicente Saénz, quien por circunstancia del azar estuvo en España en el contexto de la Guerra civil y se convirtió en corresponsal de guerra, Gutiérrez realiza este viaje a propósito de la defensa 
de un ideario. Sabe bien que su vida corre peligro, pero va empujado por el idealismo de la fe socialista que predica. Al final, sale ileso y, como un héroe romántico, da cuenta de las vicisitudes de la experiencia.

\section{REPORTERO EN LA URSS}

El tercer texto de Joaquín Gutiérrez que relata la experiencia de una estadía en un país socialista se titula La URSS tal cual. Fue incluido en las obras completas de 1989. Se trata de la recopilación de algunos textos periodísticos que el autor publicó durante sus cuatro años de estadía en la entonces Unión Soviética. Había llegado a Moscú en 1962 y para el año 1965 había visitado doce de las quince repúblicas soviéticas y había "recorrido de Vilnius a Samarcanda, de Leningrado a Bakú, conocido etnias y culturas antiquísimas y visitado rincones y ciudades que muy pocos extranjeros conocen, como Ufá, Astrakhán, Gori, el lago Issik Kul, Cheboksari, Bujara y muchos más" (1989, p. 257).

Más que una crónica de viaje, La URSS tal cual es un documento histórico que da cuenta de la situación política y social de los soviéticos. Sin embargo, contiene algunos artículos que se refieren a las vivencias cotidianas del autor y su familia en Moscú. Cuenta que llegó a esta ciudad en julio de 1962 y que los primeros meses "los vivimos sembrados de no pocas dificultades de orden práctico. Fueron en realidad un aluvión de experiencias nuevas, algunas aleccionadoras y útiles, otras ingratas" (1989, p. 425). Gutiérrez se va a vivir con su familia. Primero llega con Elena, la hija menor y, a finales de ese año, se le unen la esposa y Alejandra, la mayor. Se refiere a la cotidianidad de la siguiente manera:

Una de las tareas más ingratas era llevar la ropa a la lavandería. Con mis hijas la odiábamos y nos turnábamos (aunque, para ser sinceros, debemos confesar que las sábanas las cambiábamos una vez al mes). Había que partir con el bulto de ropa al hombro, caminar, por calles resbaladizas como jaboncillo con el hielo, tres cuadras largas, hacer una enorme cola en un local subterráneo muy helado y, por peor de todo, Ilenar una planilla con el número de camisas, camisetas, fundas, etc., para lo cual había que reconocer esas palabras, pues estaban, naturalmente, impresas en ruso en el formulario (1989, p. 426).

En la presentación que hace del pueblo soviético, busca anécdotas que den cuenta del modo de ser de la gente. Le interesan sobre todo aquellas que tienen un contenido humorístico. Por ejemplo, cuenta que, a pesar de los severos que son en los hospitales, los soviéticos se las arreglan para llevarle vodka a los enfermos y estos aprovechan para brindar con los visitantes. En una ocasión en que visitaba a un amigo uruguayo, los enfermos del cuarto, aprovechando que era primero de enero, improvisaron una fiesta. Gutiérrez describe la escena del siguiente modo: "Sacaban botellas que habían escondido hasta detrás de las vacinillas. De repente una enfermera entró y los descubrió. Comprensiva, cerró rápidamente la puerta para que el escándalo no se escuchara afuera" (1989, p. 425).

En la tesis titulada Ficción y realidad en el discurso periodístico de las crónicas de viajes y de guerra de Joaquín Gutiérrez Mangel (2017), la periodista Patricia Blanco acota que en este libro el autor expone una radiografía de las transformaciones de la sociedad soviética, principalmente en torno a temas tales como: la descentralización de la economía, el mejoramiento de la dirección colectiva del Estado, el desarrollo creador del marxismo, el derecho al trabajo garantizado, las grandes inversiones en la agricultura y sus resultados, el cambio en la mentalidad de la población y la reaparición de la 'opinión pública'.

En este sentido, como ya se acotó, este libro no es propiamente un documento autorreferencial, pero la presencia del escritor como residente en Moscú tiene un efecto de autoridad testimonial. Por lo tanto, las informaciones que se brindan, por una parte, están garantizadas gracias a la investidura del periodista que informa in situ. Pero, por otra parte, por las mismas razones ideológicas que hemos venido señalando, hay una intención propagandística, más allá de las dificultades cotidianas de adaptación que experimenta el escritor. 


\section{EL TRATAMIENTO DEL CAMARADA CALUFA}

En 1954, Carlos Luis Fallas (Calufa) viaja por primera vez a la Unión Soviética por razones de salud. Va a realizarse exámenes y a recibir un posible tratamiento para enfrentar su endeble salud, afectada por su antigua ocupación como peón agrícola en las bananeras. Su condición de camarada y líder comunista en Costa Rica le garantizan un tratamiento especial. De acuerdo con el historiador Iván Molina, en una serie de cartas que Calufa le dirigió a su tío Juan se muestran dos aspectos del escritor: "el de un paciente costarricense con el sistema de salud de una de las principales potencias mundiales de esa época; y el de un militante comunista de un pequeño país centroamericano con los logros, de todo tipo, alcanzados por la sociedad líder en la construcción del socialismo (Fallas citado en Molina, 2013, p. 21). Estas cartas a su tío forman parte de un relato inconcluso que el autor había denominado como Desde el Nuevo Mundo. Están incluidas en la compilación de textos autorreferenciales titulado De mi vida (2013) que realizó Iván Molina 6 .

El único texto editado en vida que da cuenta de un viaje es Un mes en la China roja. Fue publicado por entregas en el periódico Adelante en 1957 y se reimprimió, veinte años después, en la Editorial de la Universidad de Costa Rica. Es un relato menos personal que Desde el Nuevo Mundo, pues resulta una especie de informe de la participación de Fallas, en 1956, en el VIII Congreso del Partido Comunista de China, en representación del Partido Comunista de Costa Rica. De acuerdo con Molina, "ambos escritos

6 Como una nota curiosa en relación con este viaje, según el historiador Iván Molina, el 27 de setiembre de 1954, el periódico La Hora informó que, en un barco procedente de Checoslovaquia, las autoridades aduanales de Limón encontraron "un paquete de propaganda sovietizante consignado al dirigente de la misma ideología, Carlos Luis Fallas". Entre las publicaciones decomisadas, figuraban El Comité Regional Clandestino actúa, de A. Fiodorov; Somos hombres soviéticos, de Boris Polevoi; La Historia del Partido Comunista de la Unión Soviética, redactada por una comisión de dicha organización política; un tomo de las obras completas de José Stalin y la Revista Mensual de Literatura Soviética. Los materiales fueron enviados al Ministerio de Hacienda, "el cual -a su vez- dispuso poner el asunto en conocimiento de la Procuraduría General de la República para los efectos consiguientes". Dos días después, Fallas explicó públicamente que las publicaciones decomisadas no tenían como objetivo ninguna propaganda política, pues eran de su propiedad. Las había empacado en una pequeña caja de cartón, la que llevó personalmente a la oficina correspondiente, en Praga, donde pagó su transporte marítimo hasta Costa Rica. comparten el optimismo derivado de la experiencia de asistir a la construcción de la utopía socialista" (2013, p. 21).

El texto Desde el Nuevo Mundo, fue fechado el 15 de julio de 1955, lo que significa que Calufa trabajó en el documento hasta un año después del viaje y luego desistió. De acuerdo con el documento, la llegada a Moscú ocurrió el 13 de marzo de 1954. Pasa primero a Ámsterdam y de ahí se dirige en avión a Praga.

Al igual que lo hará Joaquín Gutiérrez, cuando el avión pasa la frontera y entra a territorio Checoslovaco, Carlos Luis Fallas aprovecha el contexto del vuelo para evidenciar que la metáfora de "la cortina de hierro" es una construcción sin fundamento. Lo consigue mediante la siguiente conversación con un periodista italiano:

— iTodos italianos?

—Sí. Muchos italianos —afirmó.

— ¿Delegados?

—iOh , no, no! —aclaró él, ahogándose de la risa—. ¡Comerciantes!... ¡Burgueses...!

Entonces yo, en tono de fingido asombro, inquirí:

— ¿Y la cortina de hierro?

— ¡Bah...! ¡Tonterías! —exclamó con desprecio el periodista. Y los dos nos echamos a reír (2013, p. 69).

De la estadía en Praga destaca la amistad que hace con el ascensorista del hotel, quien no tiene idea de donde queda Costa Rica. Tiene dificultad para Comunicarse con el trabajador, pero consigue hablar de fútbol, pues el checo sabe del tema.

El siguiente punto del viaje es Kiev. Cuando aterriza lo llevan al restaurante del aeropuerto donde le ofrecen una sopa y luego lo regresan al vuelo que se dirige hacia Moscú. En la capital soviética lo está esperando Costia, un camarada que habla castellano, 
quien se encargará de llevarlo al hotel y acompañarlo durante su estadía.

Fallas llega en el contexto de las elecciones del Soviet Supremo de la URSS. Cuenta que en una de las primeras salidas a la ciudad se dedicó a seguir a un grupo de electores a uno de los centros de votación. La junta electoral era presidida por un ferroviario condecorado varias veces, "el cual nos informó que ya a esas horas había pasado lo más intenso del trajín electoral" (2013, p. 76). Junto con los acompañantes rusos, visita otros distritos de la ciudad y comprueba que las juntas electorales estaban instaladas en los más importantes edificios. Agrega que:

Las elecciones soviéticas constituyen una verdadera fiesta nacional: el pueblo participa en ellas con entusiasmo, consciente de que ese día confirma con sus votos la elección de los mejores ciudadanos, cuyas candidaturas han surgido por aclamación en democráticas asambleas de fábricas, minas, barrios y koljoses, de todos los variados centros de producción en donde el nuevo hombre soviético vive hoy dedicado con alegría al trabajo pacífico y creador (2013, p. 76).

Previo al tratamiento médico, Calufa se dedica a recorrer Moscú y entre otros sitios asiste al teatro de la ópera, aunque confiesa que no es fanático de este género artístico. Justifica que esta poca afición se debe a su condición de obrero, al que le faltó cultura artística. A diferencia, los soviéticos valoran mucho más el arte. Prueba de ello, opina, son las jóvenes rusas que cuando asisten al teatro "vienen a disfrutar del Arte, no a exhibirse ni a coquetear" (2013, p. 77). Le parece también que los pacientes del hospital Sokolniki, que comparten con él, tienen un alto nivel, pues son aficionados a la lectura. Sobre ellos, apunta:

Todo el tiempo están con la revista o el libro en la mano, leyendo y, casi siempre tomando notas. Me he interesado en averiguar qué leen, observando con disimulo las ilustraciones. Y resulta que la mayoría, así los jóvenes como los viejos, más que leer estudian en revistas científicas y en textos de Matemáticas, de Geometría, de Física Aplicada, etcétera. Estas observaciones me han hecho pensar en mi superficial y desordenada manera de leer, que me propongo cambiar radicalmente para sacar así mayor provecho del tiempo que dedico a la lectura (2013, p. 84).

La admiración que siente por la escena cultural de Moscú se proyecta también al ámbito arquitectónico. Acompañado de un colombiano que reside en Moscú, va a conocer el metro. Considera que el de esta ciudad no tiene punto de comparación, ni siquiera con el de París o Berlín, pues "aquellos fueron hechos con sentido comercial, con afán de lucro; por eso son sórdidos y hasta malolientes. Este ha sido construido para el servicio del pueblo" (2013, p. 87).

Si bien el destinatario de estos escritos es su tío Juan, al agrupar las cartas, un año después, con intención de una posible publicación, se advierte que Calufa tenía en mente un público meta más amplio. Esto explicaría la recurrencia a información propagandística que hace alusión al éxito del modelo socialista. Por ejemplo, cita que antes de la Revolución, solo el dos por ciento de la población sabía leer y escribir en Uzbekistán. Ahora este panorama es totalmente diferente:

En setiembre de 1920, y por decreto que lleva la firma de Lenin, se creó la Universidad de Tashkent y se comenzó a organizar la enseñanza superior en todo el Asia Central. Para darle su primer impulso a esa Universidad vinieron de Moscú y de Leningrado profesores y técnicos, con el material de enseñanza correspondiente. Ahora hay treinta y seis institutos de Enseñanza Superior, cuarenta mil estudiantes y, solo en Biología, cuatrocientos aspirantes a doctorado y decenas de doctores en dicha ciencia (2013, pp. 96-97).

Sin embargo, al ser un documento que realmente envió desde Moscú, la enunciación familiar es el motivo central de las epístolas; por esta razón, en una de las misivas acota una posdata en la que le comunica a su tío Juan lo siguiente: 
Tuve que romper el sobre para hacer este agregado, que te escribo desde el apartamento de Ana Ivanova. Hoy viernes 9 de abril, por la mañana, me dieron la salida en Sokolniki. Allí dejé, en un grueso libro de observaciones, unas cuantas líneas de sincera gratitud. ¡Al demonio todas las enfermedades! ¡Salud, salud, saluuuud! Estoy hecho un toro, un búfalo, un verdadero mastodonte. Ahora pasaré a manos del oculista, para que me arregle los ojos, y después a las del dentista. ¿Qué tal? ¡Cuando llegue a mi barrio nadie me va a conocer! (2013, p. 85).

Según el diagnóstico médico, la afección que padece el escritor es producto de los parásitos intestinales adquiridos durante sus trabajos como peón agrícola. Una vez que ha concluido el tratamiento médico y que se ha descartado cualquier otra patología, con la sensación de estar renovado, Calufa aprovecha para visitar otros puntos de la Unión Soviética. Destaca la visita a Leningrado, ciudad sobre la que le transcribe a su tío algunos datos que parecen tomados de un texto enciclopédico. Le explica que en "el año 24 la ciudad pasó a llamarse Leningrado, en honor a Vladimir Ilich Ulianov, el genio de la Revolución Socialista que marcó el inicio de una nueva y superior etapa en la historia de la humanidad" (2013, p. 120).

\section{LA ESPERANZA ROJA DE LA REVOLUCIÓN CHINA}

El siguiente relato de viaje corresponde, como ya se ha indicado, a una visita que hizo Carlos Luis Fallas a China durante el año de 1956. Antes de llegar a Beijing, pasa por Ulán-Bátor, la capital de Mongolia. Desde el avión, rumbo hacia la capital china, describe los picachos nevados, las cadenas de montañas áridas y los pequeños caseríos. El gris amarillento de los valles resecos le parece triste; sin embargo, más allá de esa imagen hay un mundo de vitalidad humana.

Como ya hemos acotado, es recurrente que los escritores socialistas idealicen el modelo político que encuentran en los países al otro lado de la "cortina de hierro". Calufa, en esta misma línea, presenta a la nueva China del Gobierno Popular como un sistema que ha logrado repartir la tierra y ha tenido éxito en la organización de la agricultura, al punto de que terminó, según el autor "para siempre" con el espanto del hambre. En palabras del escritor: "...con la organizada ayuda de centenares de miles de heroicos campesinos, está realizando la doma de los dragones más implacables, de los ríos más turbulentos (2013, p. 148).

También propone que el cambio alcanza el ámbito del machismo, pues antes del régimen el nacimiento de las mujeres era considerado una desgracia. Además, ellas tenían la obligación de rendirles respeto y sumisión a los varones de las familias, y podían ser ultrajadas si al marido se le antojaba. Calufa asegura que esta práctica igualmente ha cambiado para siempre.

Uno de los sitios que visita es una granja llamada Perfume Brillante que pertenece al Estado. Ahí cada uno dispone de una parcela para su propio cultivo. Le impresiona el hecho de que si un matrimonio así lo desea puede trabajar tanto el hombre como la mujer con igual sueldo y solo el tres por ciento de este salario es requerido para el pago del alquiler de la casa. Por doce yuanes al mes pueden comer, durante tres tiempos al día, en un comedor colectivo. A todo ello agrega que cuentan con un "club, baños, guardería infantil, cine, campo de deportes, asistencia médica, salario corrido en caso de enfermedad, setenta y dos días de descanso pagado para las parturientas, etc" (2013, 156). La granja tiene 1300 hectáreas de tierra. De esta extensión, una pequeña cantidad se utiliza para producir semillas de cereales, cien hectáreas para horticultura. Todo el resto está dedicado al forraje.

Para probar el éxito del modelo, recurre a la cuantificación precisa. Esta información, a propósito de la citada granja se resume de la siguiente manera: "26 535 árboles frutales, de los cuales 7000 estaban en producción. Un personal de 537 individuos, entre obreros, técnicos, especialistas y empleados. Ocho tractores medianos y pequeños, arados mecánicos y tres segadoras combinadas" (2013, p. 157). 
Otro de los tópicos que discute es el problema del surgimiento de una burguesía nacional en la nueva China. Este tema le llama la atención, pues parece paradójico; por lo tanto, se dedica a indagar más a fondo. Con base en las propias fuentes comunistas, descubre que este asunto se maneja con flexibilidad e, incluso, tiene la oportunidad de entrevistar a un representante del comercio chino y dos industriales de Shanghai.

El problema religioso en la China comunista también es objeto de su interés. Sobre el impedimento de injerencia ideológica de las iglesias extranjeras se pregunta cómo resolvieron este problema los cristianos chinos. La respuesta es que lo lograron rompiendo todo nexo de sus iglesias con misioneros extranjeros. Se permite la libertad religiosa y de culto, pero, eso sí, la jerarquía clerical es totalmente china, igual que el dinero que se maneja (2013, p. 171).

Las marcas autorreferenciales dan cuenta de las caminatas por Beijing y algunos de los pueblos aledaños. Así, por ejemplo, el 30 de setiembre, temprano, sale de la capital en compañía de otros latinoamericanos y tres chinos. Van en cuatro automóviles con suficientes provisiones para todo el día. Durante el recorrido, relata cómo poco a poco pierden de vista las murallas y los edificios de la ciudad y avanzan durante varias horas por una carretera que los lleva por aldeas, bosques y valles. Bordean barrancos y un río que zigzaguea en un ascenso hacia unas montañas que pinta de color azul. Luego descienden por un camino estrecho, entre un paredón y un río, "y de pronto nos vimos en una explanada y entre antiguas construcciones donde hace siglos se alojaron los guardianes de una de las tantas puertas de la famosa Gran Muralla de la China" (2013, p. 187).

Otro de los recorridos que relata son los que hace a Nankín, a U-shí, a un lago Ilamado Tai-jú y al río Yangsé. Para llegar a Yangtsé, el mayor río del país e, incluso, del continente asiático, viaja en tren hasta una de las orillas. Aquí aborda un ferry que lo conduce al otro lado. Además de estas visitas al interior de China, el escritor costarricense aprovecha la estadía para recorrer algunos puntos de interés en la capital. Como escritor le interesa particularmente la tumba de Lu Xun, (que por cierto trascribe como Lui Shin y Lu Hsun). Se trata de un autor que es considerado como el padre de la literatura moderna en China. FaIlas trascribe algunos datos biográficos del escritor y agrega que "además de fecundo y destacado literato, fue un pensador profundo y un ardiente revolucionario" (2013, p. 226).

Si bien este texto es un documento que relata una experiencia de viaje y da cuenta de algunos de los recorridos que hizo, en algunas de sus partes se asemeja más a un ensayo académico que aborda diferentes tópicos de la cultura china. Esta enunciación didáctica se refuerza mediante citas bibliográficas y referencias histórico-culturales.

Fallas no oculta la admiración que siente por el pueblo chino y, especialmente, por el modelo socialista que la rige. El relato cierra con una emotiva despedida en la que los califica de nobles y heroicos y les atribuye un papel relevante en los destinos de la humanidad:

¡Adiós querido pueblo chino, gigante socialista, heroico, inteligente, sencillo y bueno! ¡Tu inmenso y generoso corazón pesará decisivamente en los destinos de la humanidad, inspirando con su poderosa presencia la lucha de liberación de los pueblos sojuzgados y contribuyendo a garantizar con sus fuertes latidos un porvenir de paz, de justicia y de felicidad para todos los hombres del mundo! (2013, p. 232).

En 1965, Carlos Luis Fallas atraviesa por última vez "la cortina de hierro". Esta vez se dirige a Moscú junto a su esposa, Zahyra Agüero. Igual que en la primera ocasión, también visita el sistema médico para que le evalúen una pequeña protuberancia que le había salido en la ingle. En Costa Rica había recibido la oferta de ser intervenido quirúrgicamente, pero el escritor, que no tenía consciencia de la gravedad, decidió atenderse en la Unión Soviética. Aquí le anunciaron la terrible noticia de que tenía un cáncer de riñón que ya había hecho metástasis. Calufa no tuvo oportunidad de referirse a este último viaje. Murió unos meses después, pero su contribución a la literatura de viajes, de todos modos, ya estaba hecha. 


\section{EL SOL QUE ALUMBRA EN CHINA}

En 1960, el escritor Adolfo Herrera García publica el libro China de día, donde relata las experiencias de un viaje que realiza a China, durante mes y medio, justo ese mismo año. Previamente, el autor había estado allí en 1952, así que esta segunda estadía tiene como referencia inmediata la anterior. Se trata, entonces, de una visita que ocurre ocho años después de la primera. Esta circunstancia le permite hacer comparaciones sobre las trasformaciones que ha experimentado la gran nación asiática en este lapso. Los cambios referidos, según el texto, dan cuenta del éxito del modelo socialista. Considera que hace ocho años aún existían resabios feudales en la economía, pero la reforma agraria ahora ha hecho que esto cambie de manera radical.

A lo largo del libro, Herrera contrapone las memorias de una China subdesarrollada con la constatación de los avances que encuentra en este segundo viaje. El país ha pasado de los grupos de ayuda mutua y de las cooperativas de grado inferior a la comuna. Ahora la propiedad es social, pero existen grados de propiedad sobre determinados medios de producción. Como resultado, la comida ahora es gratuita (1960). Abundan, también, los datos duros con los que pretende demostrar los "grandes" avances que han ocurrido desde que arrancó el modelo socialista: "Antes había 23, 000 médicos. Ahora, 86.000. Hay 106 veces más instituciones de salud pública que antes de la liberación y 142 escuelas y 382 preparatorias de medicina" (1960, p. 45). Al igual que lo harán otros de los autores de izquierda de esta época, Herrera enuncia un discurso encomiástico en defensa del modelo político. Afirma que: "Lo que han realizado en ocho años no lo hubieran hecho en el régimen de la propiedad privada (en carreta) ni en medio siglo" (1960, p. 9).

Junto con otros periodistas latinoamericanos, Herrera visita el noreste del país. Durante el recorrido conversa con diversos actores sociales: niños en las escuelas, amas de casa, campesinos de las comunas populares, con escritores y dirigentes del gobierno, entre otros. Además, visita fábricas, colegios, comunas e, incluso, museos. Asegura que, frente a todos estos personajes y sitios recorridos, el reportaje que ofrece será una tarea compleja. "Así es que no hay más remedio que esbozar apenas una parte de lo que vi, averigüé y palpé en mes y medio en la República Popular China, habitada por la tercera parte de la Humanidad" (1960, p. 11).

De acuerdo con los defensores del Socialismo, el éxito de esta doctrina se prueba en lo cotidiano. Adolfo Herrera sostiene esta tesis y asegura que esta ideología garantiza la máxima justicia social. La visita se convierte en una constatación in situ de esta condición promisoria. El escritor predica esta fe política y a donde va encuentra razones para demostrar su teoría. Las pruebas se acompañan de enunciados axiológicos que idealizan el paisaje humano y la capacidad constructiva de los chinos.

A propósito de la canalización del río Huai, considera que este "fue un monstruo durante dos milenios para millones de seres humanos. Pero el socialismo lo domesticó, lo humanizó y lo puso al servicio del hombre. Vencer la naturaleza es civilizar" (1960, p. 11). En consecuencia, el modelo político va más allá de las reformas que garantizan la igualdad social y actúa como un poder antropocéntrico capaz de vencer lo natural para ponerlo al servicio del ser humano. El progreso, en este imaginario de "modernización" se entiende como la superioridad del ser humano para doblegar la naturaleza. Este mismo sentido industrial, entendido como la eficiencia en la administración de los recursos, está presente en el exceso de datos estadísticos que aparecen a lo largo del libro. Es evidente que el escritor tiene a mano informes que detallan los resultados del gobierno. Estos documentos resultan oportunos para incluirlos en la publicación. Esta información cuantitativa se inserta como parte de las acotaciones referenciales que hace durante sus recorridos. Véase, como ejemplo, estas acotaciones a propósito de una visita a un barrio obrero:

Aquí viven trabajadores como los que hemos observado en la fábrica de cables y alambres eléctricos. Hay 350 edificios de 3 o 4 pisos. Todos de concreto. Tienen luz, agua y calefacción. Este barro alberga a 8.000 familias con 91 mil habitantes. Casi como San José. Hay pequeños comercios y grandes comercios. Yo 
compro una gorra y una guerrera chinas, de color azul. Me cuestan 8 yuanes (1960, p. 22).

El escritor se percata de que en su relato sobreabundan los datos de carácter estadístico y supone, como es lógico, que este estilo podría aburrir a los lectores. Para enmendar el tedio que podría producir este referente numérico, recurre a una estrategia apelativa en la que propone un supuesto diálogo con el lector:

EL AUTOR: En China, antes de la liberación...

El LECTOR: Un momento, Herrera. Déjeme descansar de las cifras y los números.

EL AUTOR: ¿Qué quiere ahora? Al fin y al cabo, usted ha pagado por tener este libro en sus manos.

El LECTOR: Como si fuera un capítulo entre paréntesis, hablemos de la vida corriente y diaria de los chinos. ¿Le parece?

EL AUTOR: ¿Algo turístico?

El LECTOR: Llámelo como quiera. Pero en lugar de estadísticas y más estadísticas...

EL AUTOR: Abramos el paréntesis (1960, p. $60)$.

Mediante este recurso retórico, Herrera intenta recuperar la captatio benevolientiae, que probablemente ha perdido como resultado de la acumulación de datos estadísticos. Esta fórmula le permite pasar a temas más autorreferenciales, como la confesión de que "el manjar más poético que comí en china fue este: harina de raíz de loto con flores de casia. Una especie de atol, del que repetí varias veces" (1960, p. 60). Luego, hace referencia a otros aspectos de la vida cotidiana, tales como: el gusto de los chinos por las aletas de tiburón, el vino de arroz, las cervezas y los cigarros.

Una vez que ha cerrado este paréntesis para dar cuenta de lo "turístico", retorna de nuevo a los datos numéricos del informe administrativo, a lo encomiástico y las formulaciones axiológicas. Por ejemplo, en Shangai se muestra sorprendido por la magnificencia de la ciudad con rascacielos y occidentalizada.
Señala que anteriormente esta era la capital de los vicios, pues aquí había casas de juego y de citas, fumaderos de opio y gánsteres. Ahora, con el nuevo régimen, esto ha cambiado y Shangai, según el escritor, recuperó la moralidad.

Esta visión deontológica impone también una prescriptiva para el sujeto que convive y comparte el mundo igualitario. Nadie puede romper el código social y los chinos, tal parece según esta visión, tienen una disciplina que asegura el éxito ideológico.

Otra de las pruebas que demuestran el éxito del modelo comunista es el papel que se le ha dado a la mujer como sujeto social. Pone como ejemplo de esto a una trabajadora que entrevista. Ella le cuenta que trabaja seis horas y que tiene dos días libres para estudiar. Asegura que antes se dedicaba a lavar y planchar todo el día y que eso la estaba "idiotizando" (1960, p. 30). A pesar de este nuevo rol, para Herrera, las chinas siguen siento fieles a su marido por convicción. Esta acotación, que desde un enfoque ginocrítico se enuncia como un claro sesgo patriarcal, es todavía mucho más machista en la siguiente argumentación, pues estas virtudes de sumisión, según el escritor, no las tiene la mujer occidental:

En nuestra sociedad aristocrática, ¿cuántas no abandonarían lo suyo si tuvieran independencia económica? No lo hacen porque les hemos achicado el pie, como a las antiguas chinas. La liberación del ama de casa, con su entrada a las tareas productivas ennoblece su vida y la de su familia, y demuestra cuán libre es la sociedad a la que pertenece (1960, p. 30).

Según esta tesis, la "inmoralidad" de la mujer occidental ha sido controlada gracias al hecho de que no tienen independencia económica y a que también se le ha achicado el pie. El trasfondo misógino contra la mujer occidental parece desdibujarse frente a la idea de la mujer sumisa y útil que encuentra en el modelo chino. Más adelante, retorna a este mismo tema y agrega otros elementos que remarcan el cliché patriarcal. Señala que las chinas no tienen como objetivo en la vida "cazar" un marido, las pinta como mujeres naturales sencillas y sin falsas coqueterías. Esta mujer "es mucho más 
útil ahora que trabaja. Encontré chinas dulces, honestas, maternales, buenas. Si yo tuviera un hijo le recomendaría para madre de mis nietos una china socialista" (1960, p. 61).

Con estas pruebas estadísticas y al mismo tiempo deónticas, Adolfo Herrera regresa a Costa Rica y publica este informe, cuya intención pragmática es claramente propagandística. El juego semiótico del título, China de día, tiene un efecto ideológico que se retoma en el cierre. Costa Rica, al igual que los países capitalistas, está en la contraparte oscura. La misión de los intelectuales, como él, es hacer que, algún día, en Costa Rica también alumbre ese modelo.

\section{LOS SECRETOS DE LA ARCADIA NUEVA}

El cuarto escritor de esta serie es menos conocido como literato, pero su libro El país del sol y la estrella, publicado en 1983, es una pieza indispensable en esta serie, pues cierra el capítulo de los viajeros que traspasaron los bordes de los países socialistas en el contexto de la Guerra Fría. Se trata de Mario León $\operatorname{Rojas}^{7}$ (1942), un poeta, narrador y periodista que se identificó con el modelo de la República Popular Democrática de Corea, un país que hasta el momento carecía de referencias en el género del viaje costarricense, entre otras razones, porque formaba parte de los territorios de la ocupación soviética. La visita de León ocurre a finales de 1982 y el libro lo publica una editorial denominada Independencia, a inicios del siguiente año.

Mario León pertenecía al Instituto Costarricense Coreano y, desde esta institución, constató que en Costa Rica se sabía muy poco acerca de Corea del Norte y su historia (1983, p. 5). Esta circunstancia lo llevó a la determinación de escribir un libro sobre este

$7 \quad$ De acuerdo con Óscar Barboza Lizano, quien publica una semblanza del autor en Repertorio Americano, Segunda nueva época, plantea que la obra publicada por Mario León en Costa Rica se concreta en los siguientes títulos: "Rescate, en su primer libro (Editorial Líneas Grises), Milagro cotidiano (Biblioteca Rodante), El país del sol y la estrella (Editorial Independencia), El último paseo y otros cuentos (Ediciones la Llave), Encrucijada (Ediciones la Llave), Almas gemelas (Ediciones La Llave), Diálogos para jefaturas (su texto de mayor tiraje, cerca de 15 mil ejemples" (2013, p. 86). El libro completo de la penúltima referencia es Almas gemelas y otros asombrosos amoríos. Se trata de un texto de relatos publicado en el año 2002. También, tiene publicado un libro de poesía que se titula Génesis (Ediciones la Llave, 2015). país. Para concretar el proyecto, se propuso hacer un viaje y tener información de primera mano. En consecuencia, en principio, la gira tuvo una función más didáctica que política. Sin embargo, la postura de identificación que, de manera abierta, mantiene el escritor a favor del modelo político llamado Juche, incide en una impronta ideológica que se advierte en la escritura.

Para llegar a Pyongyang, la capital de Corea del Norte, León debe volar primero a Moscú. Este trayecto, no solo es lógico por conexión aérea, sino también por obvias razones de vínculo en el contexto geopolítico de la Guerra Fría.

Al llegar a su destino, el escritor fue recibido de manera oficial. Cuenta que en el aeropuerto "una niña de porte gentil me ofreció un ramo de flores y una sonrisa jovial, plena de una alegría inefable y del regocijo con que el pueblo coreano acostumbra a recibir a sus visitantes" (1983, p. 2). Luego, una comitiva lo acompaña al Hotel Pyongyang, en donde se hospedará durante los días de la visita. Aunque el texto no lo dice de manera explícita, gracias a este recibimiento se infiere que la visita había requerido previamente de una comunicación oficial, de modo que el costarricense llega con el visto bueno del régimen socialista. Muy probablemente los coreanos tenían conocimiento de la misión periodística y, al mismo tiempo, publicitaria, que se proponía el aliado costarricense.

León cumple puntualmente con el objetivo publicitario mediante dos estrategias discursivas concretas. Primero, mediante el tradicional tono encomiástico y, segundo, gracias a la abundante información referencial sobre la historia y la situación de sistema norcoreano en ese momento. Es decir que hay una mirada diacrónica y sincrónica a la vez.

El efecto laudatorio se consigue a través de la enunciación subjetiva. El viajero recorre distintos puntos de Pyongyang y desde la mirada in situ describe un escenario casi perfecto:

Probablemente lo que más me conmovió fue la sensación de encontrarme en una ciudad como no había conocido otra, donde todo 
está hecho de manera que uno se sienta libre, dueño de amplias avenidas, de los monumentos levantados para nuestro regocijo, de los parques colmados de flores y árboles, de las fuentes donde el agua se metamorfosea en arabescos y flores; dueño de esa ciudad que mansamente obedece a su amo el hombre (1983, p. 3).

A esta visión edénica donde lo urbano existe en armonía con las zonas verdes se agrega un elemento que es recurrente en la visión marxista: la idea de que la transformación de la naturaleza se concreta mediante el trabajo; por esta razón, según este ideario, el hombre es el amo de este equilibrio ético y estético. Los pueblos que se desarrollan en sintonía con los postulados del materialismo histórico marxista son conscientes de que el trabajo colectivo es el motor de la historia.

León se propone demostrar que este pueblo coreano es exitoso gracias a la organización política y a la eficiencia en la colectivización del trabajo. Piensa que podría comprenderse mejor la historia de la República Popular Democrática de Corea si se conociera "su gloriosa historia, sus tradiciones revolucionarias, su larga lucha por la independencia y la defensa de su ser nacional" (1983, p. 8). El libro será un intento por dar a conocer estas facetas y evidenciar su tesis.

En este caso, más que la promoción de un régimen pro-soviético, en concordancia con el contexto histórico político norcoreano, León hará una defensa del sistema Juche o como él lo denomina: el modelo zucheano. Es una idea que había sido planteada por Kim Il-sung cuando asumió el poder en 1948 y desarrollada por su hijo Kim Jong-il. Consiste en una adaptación local de los idearios del marxismo leninista. En su libro, el costarricense explica ampliamente este proceso histórico y defiende la garantía social del proyecto.

En sus recorridos por Pyongyang, León se detiene frente al monumento que fue levantado para conmemorar el 70 aniversario del líder fundador de la idea Juche. Al pie de la magna representación, al escritor le parece que aún resuenan en el líder "los ecos de tantas batallas y las palabras que Kim II Sung pro- nunció en el discurso ante las masas que le daban la bienvenida" (1983, p. 53). Acto seguido, transcribe la traducción de uno de los discursos memorables del líder. De este modo, el viaje resulta una excusa, de paso, para la intención didáctica e ideológica de fondo. Entre los temas que aseguran este propósito están la lucha por la liberación del país y la crítica a la invasión estadounidense, a quien acusa de provocar la guerra y de dividir Corea.

La respuesta del pueblo coreano, sin que medie en la explicación la injerencia soviética, se representa bajo los códigos de una épica nacional contra el imperialismo yanqui. Según el escritor, "el pueblo coreano reconquista su soberanía y deja una imperecedera lección para los pueblos oprimidos, a quienes demuestra que es posible vencer al imperialismo y deja una escuela de sabias tácticas y estrategias militares inspiradas en la Idea Zuche" (1983, p. 124). El siguiente paso del proyecto consistirá en reconstruir el país. Con base en el pensamiento que inspira el líder Kim II Sung y sus descendientes en el poder, según el escritor, los norcoreanos rehacen la nación de manera exitosa. Para demostrar los logros, León cita la información cuantitativa que se divulga en los boletines oficiales e insiste en que esta revolución es un ejemplo para el mundo (1983).

Si bien El país del sol y la estrella es, en principio, un texto de viaje con aspiración didáctica, en su desarrollo se convierte en un documento referencial que resulta de la admiración de su autor por el modelo político norcoreano. Esta intención pragmática, en todo caso, no es nueva. Coincide con la lógica enunciativa de la mayoría de los relatos trasfronterizos, escritos por autores socialistas, al otro lado de la llamada "cortina de hierro".

\section{CONCLUSIONES}

A diferencia de los turistas burgueses que llegan a Europa a nutrirse de prestigio o los peregrinos de la fe que visitan los santuarios religiosos, a los viajeros de este contexto de la Guerra Fría los mueve el idealismo político. Son creyentes devotos de un discurso que tiene su fundamento en los postulados del materialismo histórico, basado en el pensamiento 
de Carlos Marx y la predicción, supuestamente científica, de que la historia evolucionaría hacia los modelos de la solidaridad humana.

Desde el punto de vista geográfico, estos escritores costarricenses, identificados con el modelo socialista, quedan ubicados del lado hostil. El otro lado representa la disidencia con la que comulgan. Por esta razón, el viaje a los países del imaginario comunista va más allá de la curiosidad del explorador con ojo etnográfico o el aventurero que se precia de la intrepidez. En este caso, el viaje forma parte de una misión ideológica, algunas veces con el apoyo financiero de los países receptores, especialmente en el caso de la Unión Soviética.

La periodista Patricia Blanco, a propósito de las crónicas de Joaquín Gutiérrez, considera que hay tres aspectos que caracterizan sus viajes. Estas consideraciones aplican igualmente para el resto de los autores analizados en este artículo. Primero, se refiere a la existencia de una perspectiva político-ideológica, implícita y explícita en el discurso. Esto es evidente en los temas que priorizan los escritores, vinculados con las confrontaciones propias de la Guerra Fría: la aversión a las políticas de Washington y el beneplácito a los dictados de Moscú.

Segundo, el narrador es testigo y a veces protagonista de los hechos. Esto conlleva a los autores a identificarse no solo como viajeros, sino como camaradas; es decir, como actores políticos que mantienen una estricta fidelidad con la causa ideológica. De acuerdo con Blanco, "esta es una forma de producir ficción o de ficcionalizar la realidad, ya que el narrador, al interpretar su entorno, realiza una "traducción" de la realidad por medio del discurso" (2017, p. 187).

Esta interpretación conlleva al tercer punto que propone la periodista: la interpelación al lector. Se trata de una enunciación que se caracteriza por modalizaciones lingüísticas que buscan una cercanía con el destinatario. Cuando el escritor asume que ha conseguido la empatía, escribe con un tono más didáctico y adopta una postura de autoridad.

De acuerdo con Blanco-Picado:
Muy asociada a la perspectiva socialista, el interés por la cuestión social es otro de los rasgos discursivos que sobresale en las crónicas de Gutiérrez. El ser humano aparece como el motor de la narración y como un aspecto central de la posición ideológica asumida por el cronista. Cabe resaltar que el concepto humanístico y los fenómenos sociales son pilares de la corriente del arte comprometido y del realismo socialista en la literatura, que alcanzan su máximo desarrollo durante el contexto de la Guerra Fría, con una fuerte influencia del marxismo, como ya se ha mencionado en este trabajo. Varios textos aluden al tema de la importancia del "hombre" para el socialismo y el comunismo, al que coloca como la "razón de ser" de todo movimiento social orientado a alcanzar un estado de satisfacción plena (2017, p. 101).

Esta imagen idealizada se contrapone a la perspectiva con que Joaquín Gutiérrez mira a aquellos países que no forman parte del modelo socialista. Por ejemplo, a propósito de Brasil acota que a pesar de tener las playas más lindas del mundo y que las "garotinhnas" (mujeres) son las más lindas de la tierra, "en este país existen villas de miseria, pues en las favelas viven en racimos un millón de negros" (1989, p. 177). Una impresión igualmente negativa le produce la España franquista, a la que llama medievalista y, desde luego, el símbolo de lo más execrable es Estados Unidos.

En cambio, al igual que los demás autores de esta serie, las presentaciones que hace de los países socialistas son sumamente optimistas. La admiración no solo gira en torno al liderazgo de la Unión Soviética. También, como hemos visto, elogia la capacidad organizativa de otros países del bloque y los pone como la punta de lanza del futuro de la humanidad.

El "telón de acero" es más que la famosa metáfora que propuso Winston Churchil. Para los viajeros de la utopía pasar esta frontera implica traspasar la diferencia entre el pasado y la oportunidad de asistir al imaginario del futuro. En la mayoría de los casos van investidos con el sombrero del periodista. La crónica 
del viaje se convierte en un reportaje publicitario: la propaganda que muestra y demuestra cómo será el futuro que le espera a Costa Rica cuando por fin llegue a este lado el efecto histórico de la utopía.

De alguna manera, estos escritores son profetas, predicadores de un evangelio político. Por esta razón, los textos son documentos que muestran las proezas populares y los logros sociales. En los textos no se abordan las posibles contradicciones, la represión a la disidencia o las disputas que se dan entre Moscú y las periferias. El tono encomiástico va desde el título hasta las modalizaciones discursivas que se dedican a elogiar la épica, los logros y el paisaje humano, entre otros aspectos.

\section{REFERENCIAS BIBLIOGRÁFICAS}

Barboza-Lizano, Ó. (2013). Mario León, el escritor de la idea Zuche. Repertorio Americano. Nueva segunda época. 23(4).

Blanco-Picado, P. (2017). Ficción y realidad en el discurso periodístico de las crónicas de viajes y de guerra de Joaquín Gutiérrez Mangel (Tesis de graduación para optar por el título de Licenciatura en Ciencias de la Comunicación Colectiva con énfasis en Periodismo).

Fallas, C. L. (2013). De mi vida. En I. Molina (Ed.). Tomo I Comp. San José: EUNA.
Gutiérrez, J. (1989). Obras completas (Tomo 3). San José: Editorial de la Universidad de Costa Rica.

Herrera-García, A. (1960). China de día. San José: Imprenta Elena.

Leñero, V. \& Marín, C. (1986). Manual de periodismo. México: Editorial Grijalbo, S.A.

Mignolo, W. (1992). Cartas, crónicas y relaciones del descubrimiento y la conquista. En Historia de la Literatura Hispanoamericana. Tomo I. Madrid: Ediciones Cátedra.

Molina, I. (12 de agosto de 2017). Hogueras de literatura. La Nación. Recuperado de https://www. nacion.com/opinion/foros/hogueras-deliteratura/6 6TCYJ2NMNCMNKBPGBIYHVGELY/story/

Molina, I. (2016). Príncipes de las remotidades. CarIos Luis Fallas y los escritores proletarios costarricenses del siglo XX. San José: EUNED.

Quesada-Soto, Á. (1998). Uno y los otros. Identidad y Literatura en Costa Rica. 1890-1940. San José: Editorial UCR.

Quesada, Á. (2010). Rutas de subversión. San José: Editorial Universidad de Costa Rica.

Rojas-León, M. (1983). El país del sol y la estrella. San José: Editorial Independencia.

Rojas, M. \& Ovares, F. (1995). 100 años de la literatura costarricense. San José: Ediciones Farben. 